\title{
ADDRESSING PUBLIC ACCOUNTABILITY THROUGH IMPLEMENTATION OF BALANCED SCORECARD: CASE STUDY ON DIRECTORATE OF GOVERNMENT DEBT SECURITIES, MINISTRY OF FINANCE
}

\author{
Heri Praptomo \\ Direktorat Surat Utang Negara, Kementerian Keuangan, Email: heri.praptomo@kemenkeu.go.id
}

\section{INFO ARTIKEL}

SEJARAH ARTIKEL

Diterima Pertama

11 Agustus 2017

Dinyatakan Dapat Dimuat 6 Desember 2017

\section{KEYWORD:}

accountability,

balanced scorecard,

performance management,

Directorate of Government

Debt Securities.

\begin{abstract}
ABSTRAK
Accountability is something that needs to be in place on every business activity particularly on public sector. Parties who are assigned with authority/power in a certain public organization should be accountable. They will be watched and controlled by other parties, such as supreme audit board, society, and non-government organization, who require explanation and justification of their conduct. One of means to answer the need of accountability in governmental activities is the performance management, that is broadly designed to guide the organization achieving its visions or objectives, fostering efficiency and effectiveness. Balanced scorecard is one example of performance management tools in contemporary era. Can it be said the implementation of balanced scorecard in the government agency is an attempt to deliver accountability? By analyzing and evaluating one practice of balanced scorecard in certain organization under Ministry of Finance of the Republic of Indonesia, this paper finds that the concept of balanced scorecard can be implemented as a tool to answer the needs of public accountability. Through every scorecard built in Directorate of Government Debt Securities, this paper discovers several ideas of public accountability such as financial, process, and hierarchical accountability, have been addressed by the implementation of balanced scorecard. However, such indicator of that unit's balanced scorecard needs to be reformulated to answer other idea of public accountability.
\end{abstract}

Akuntabilitas harus terwujud dalam setiap aktivitas bisnis, terlebih pada aktivitas sektor publik. Pihak yang memiliki kekuasaan/wewenang di sebuah organisasi publik harus akuntabel. Mereka akan diawasi dan dikontrol oleh pihak lain, seperti lembaga pemeriksa (auditor publik), masyarakat, dan organisasi-organisasi swadaya (non pemerintahan) yang menghendaki penjelasan dan alasan atas tindakan yang mereka lakukan. Salah satu metode untuk menjawab kebutuhan atas akuntabilitas di sektor publik adalah melalui manajemen kinerja, sesuatu yang didesain untuk mengarahkan organisasi dalam memenuhi visi dan tujuannya, serta mewujudkan efisiensi dan efektivitas. Di era modern saat ini, balanced scorecard merupakan contoh manajemen kinerja yang diterapkan oleh banyak instansi publik. Apakah konsep balanced scorecard yang diterapkan oleh banyak lembaga pemerintahan saat ini merupakan upaya untuk menyajikan akuntabilitas? Melalui analisis dan evaluasi atas praktik penerapan balanced scorecard pada salah satu institusi di Kementerian Keuangan, artikel ini memperoleh fakta bahwa konsep balanced scorecard yang diterapkan oleh Direktorat Surat Utang Negara (SUN) telah menjawab aspek-aspek penting dalam akuntabilitas sektor publik, antara lain akuntabilitas hierarkhi, profesional, proses, dan akuntabilitas keuangan. Namun, beberapa indikator dalam scorecard yang disusun oleh Direktorat SUN terutama pada perspektif 'learning and growth', perlu diformulasikan kembali untuk menjawab aspek penting lainnya dari akuntabilitas, yakni motivasi dan pemberdayaan sumber daya manusia.

\section{INTRODUCTION}

On every business activity either profit or nonprofit oriented, accountability is phenomenon that needs to be in place. It is major concept on how to establish good governance in organization especially for the party that is given with authority and power. Particularly toward public sector, this notion is necessity to be conducted since authority/ power that has been assigned to official would be watched and controlled by other party with right doing so. In many democratic governments, accountability becomes central attribute of the democratic system. Australian government, for instance, puts accountability to ensure that parties who have authority over public resources deliver an account for the use of those resources in 
terms of compliance, efficiency, and effectiveness (Australian House of Representatives Standing Committee/ AHRSC 1990).

As primary function of public organization is delivering service to society, accountability of how officials deliver service and 'service' itself becomes fundamental. In this context, public accountability can be a tool for measuring quality of service disseminated to the public. The public officials can employ this notion to assess society satisfaction on service quality (Ahmad et al., 2005). Moreover, other scholars, Fard and Rostamy (2007) highlight that public trust towards government are determined by how the officials present service to the public and how well civil servants perform their function and program at all level.

There are many ways for the government agency to be accountable in front of those who require the accountability. One of those ways is through performing good performance by which all objectives or targets of organization are achieved. In order to ensure it, there is one concept that is fundamentally helpful towards organization, named performance management. Performance management refers to a process in which management assesses and responds how organization works against its stated mission and objectives (Siddiquee 2011). Hence, performance management is absolutely needed for every institution to monitor each process running on goals achievement and provide framework for organization to fostering efficiency and effectiveness, which are tool for accountability in public administration area.

One of contemporary ideas on performance management that broadly implemented by many organizations currently is balanced scorecard. Pioneered by Robert S. Kaplan and David P. Norton in 1990s, the balanced scorecard idea is actually designed for business entity but it becomes popular for public agency as a tool for performance management and strategic management system nowadays. The concept of balanced scorecard principally locates on how the managers look at the business from four important perspectives within organization, which are financial, customer, learning and growth, and business process (Kaplan \& Norton 1992).

Regarding those concerns, could it be said that the implementation of balanced scorecard in public sector is one attempt to deliver accountability? This paper will explore this question briefly by analyzing and evaluating one instance of the implementation of balanced scorecard in public agency, named by Directorate of Government Debt Securities (DGDS) in 2016. The discussion would be delivered through four sections. The first section will explore literature studies on accountability, performance management, and the idea of balanced scorecard. The second section describes the practice of balanced scorecard in the DGDS. The third is the main discussion addressing that question. In this section, I will answer the question by addressing three main questions, which are can the balanced scorecard ideas answer the need of accountability in public organization, does applied balanced scorecard in DGDS address public accountability, and which type of accountability the DGDS's balanced scorecard answers for. The final is the conclusion of the discussion.

\section{THEORETICAL FRAMEWORK}

\subsection{Accountability}

Toward public organization, accountability is the real concern that needs to be in an account. It has specific features that derive from the nature of responsibilities and the centrality of relationship with politicians (Halligan 2001). Romzek and Dubnick (1998) define accountability as a relationship between individuals or agencies that are assigned authority to act and the performance those parties have made with that authority. The term 'relationship' can be understood as an explanation or a justification of his or her conduct and questions from other party on that explanation or justification (Bovens 2007).

According to Behn (2001), there are three types of accountability in public administration sphere, which are accountability for finances, accountability for fairness, and accountability for performance. Financial accountability refers to the use of taxpayer's money. The public officials have an obligation to spend that money wisely because they have been assigned with it by the society. Accountability for fairness represents how the government agency treats all citizens mutually. Performance accountability reflects how well the organization works out against the society's expectation on the outcomes or results.

Additionally, there are four ladders of accountability promoted by Stewart (1984) that public organization ought to meet, consisting of policy accountability, program accountability, performance accountability, process accountability, and probity and legality accountability. Policy accountability requires the public entity to meet the decided policy objectives. Program accountability ensures all program outcomes are achieved by the agency while performance accountability represents the achievement of planned outputs. Process accountability refers to the compliance with the procedures, efficiency, and equality on causes. Accountability for probity and legality underscores the approval of fund spending and ensure no fraud and no legal power exceeded.

In terms of relationship built in accountability concept, other scholar, Romzek (2000) acknowledges four different accountability relationships: hierarchical, legal, political, and professional. Hierarchical accountability refers to the employee's obedience to organization directives and supervision while the legal one emphasizes the compliance with an external mandates. Political accountability is about responding to the external stakeholder expectation or agenda. Professional accountability reflects the consistency with the professional criteria, standards, or norms. 


\subsection{Balanced Scorecard}

Kaplan and Norton (1996) highlight balanced scorecard as a new framework for integrating performance measures derived from vision and strategy of the company. This scorecard translates company's vision and strategy into objectives and measures that cover past and future performance (strategic management system). Past performance encompasses financial aspect while future one reflects sustainability of the organization that incorporates three perspectives: customer, internal business process, and learning and growth. These three other perspectives complement financial measure that is not able to drive organization in competitive environments as experienced by Xerox during the mid of 1970s whereby this company was almost failed due to over emphasis on profit growth regardless the quality of service and customer satisfaction.

Accordingly, in this concept, there are four major perspectives that are complementary and integrated each other drive the organization reaching its objectives and goals (Kaplan \& Norton 1993). Financial perspective refers to what the shareholders want from company. It indicates economic consequences of actions already taken by management. Financial measures typically focus on profitability of the organization, such as incomes, return on investment, and sales growth. Customer measure represents how the customers see the company. It describes how well company delivers services or products to the consumers, among other, containing customer's satisfaction, loyalty, and retention. It also enables the organization to identify targeted customer and market segments. Internal business process perspective reflects the critical process that must be excelled thoroughly by company to meet customer and financial objectives. Lastly, learning and growth perspective acknowledges what the organization has to do to create improvement and long-term growth. It articulates the needs of investment in the organization's infrastructure - human resources, system, and procedure - to sustain other three perspectives objectives.

Nowadays, the use of balanced scorecard approach is not only situated in business sector but also in public agency. Private entity implements balanced scorecard to improve bottom-line performance in which shareholder value is the main end (Niven 2003) whereas for public sector, balanced scorecard idea can be exercised to tackle deficiencies and insufficiencies of the traditional performance evaluation system (Agca \& Tuncer 2006). Instead of demonstrating advantage over traditional measurement approach, Niven (2003) acknowledges other benefits of using balanced scorecard in government agency, among others, attract scarce resources particularly on funding and employees, endorse government institution to focus on strategy leading to the achievement of mission, produce reliable information rather than data only, demonstrate quality results at efficient prices (self-preservation), drive change within organization, and secure public or society trust to the organization.

\section{RESEARCH METHOD}

The paper will be delivered by qualitative method, conducted toward DGDS's balanced scorecard. Through this method, analysis, observation, and interpretation on DGDS's scorecard are accomplished to get picture how the scorecard works, followed by, then, comparison with ideas of public accountability to see patterns and connections between the scorecard and public accountability. Furthermore, assessing their patterns and connections will be carried out to seek findings and conclusion on how far the balanced scorecard answers the needs of accountability in public sphere.

\section{FINDINGS}

4.1. Implementation Balanced Scorecard in Directorate of Government Debt Securities

As a part of bureaucracy reform agendas which have main objectives to institute good governance in managing state finance, and to build the public trust through improving public services, Ministry of Finance decided to put performance management into main account of this reform agenda. In delivering performance management agenda, the Minister has chosen the concept of balanced scorecard to be an element of performance management system for all departments under Ministry of Finance. The Minister then issued Ministerial decree number 467/KMK.01/2014 regarding 'Performance Management in the Ministry of Finance' as a mandate for all department under Ministry of Finance to establish balanced scorecard as a performance management tool.

The DGDS, one of echelons-II in Ministry of Finance, has succeeded creating balanced scorecard for those performance management needs. This created balanced scorecard was made to manage the achievement of DGDS's vision, which is to fulfilling budget deficit through issuing and managing government debt securities (GDS) efficiently and prudently. In 2016 national budget, the DGDS must find financing amounted to roughly IDR474.42 trillion. GDS is Indonesian government bond that consists of treasury bills - popularly called T-bills: a short-term bond (matured in less than 1 year), fixed bond, variable bond, retail bond, zero coupon bond, and international bond which includes Global bond in US dollar and Euro currency and Samurai bond in Japan yen currency.

In practice, balanced scorecard in DGDS is established with one adjustment in the one of the original perspectives, which is financial perspective. As highlighted above, financial perspective represents what the shareholders desire from the company in terms of financial matter, which is mainly profit, DGDS will not be fit with this idea because it is not profitoriented organization. Hence, DGDS reconfigured this perspective with the term of 'stakeholder perspective' that has closed meaning with financial perspective. 


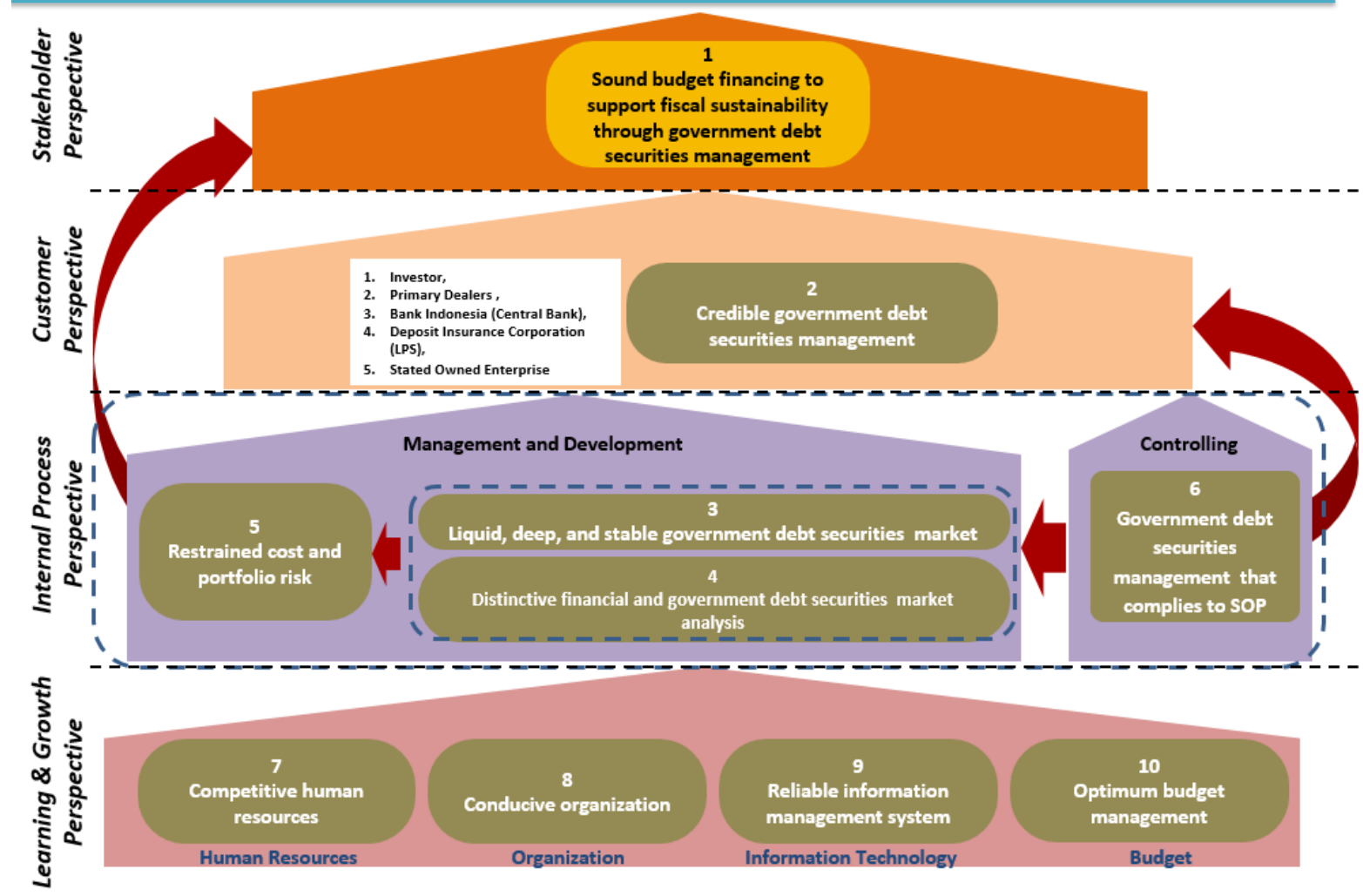

Source: Strategy map of Directorate of Government Debt Securities, Ministry of Finance

Figure 1. Cascading Process of Balanced Scorecard in DGDS

Akin to financial one, stakeholder perspective was designed to capture what the stakeholders require from the organization but not in terms of financial matter rather in terms of objectives/ outcomes accomplishment.

As explained above that balanced scorecard is not only performance appraisal method but also strategic management approach, all objectives of DGDS have been developed by complying them with the vision statement and considering the four perspective of balanced scorecard. This means scorecards of DGDS performance that consist of stakeholder, customer, learning and growth, and business process perspective represent the vision statement and reflect the objectives of DGDS in issuing and managing government debt securities. These objectives have also been developed through cascading mechanism to bridge the considerable learning gap that exists between lowest level and highest level of the organization. This will ensure the objectives of lower level groups align with the highest-level one, so the lowest one can contribute to overall success of the organization. The cascading process of balanced scorecard establishment in DGDS can be drawn in figure 1.

Figure 1 shows that to reach the vision, the DGDS has instituted eleven annual objectives that enclose all four perspectives within balanced scorecard ideas, consisting of:
1) Stakeholder perspective:

Sound budget financing to support fiscal sustainability through GDS management.

2) Customer perspective: Credible GDS management.

3) Internal business process perspective:

a. Liquid, deep, and stable GDS market,

b. Distinctive financial and GDS market analysis,

c. Restrained cost and portfolio risk,

d. GDS management that complies to SOP.

4) Learning and growth perspective:
a. Competitive human resources,
b. Conducive organization,
c. Reliable information management system,
d. Optimum budget management.

Each of those objectives is broken down into several key performance indicators (KPI) that comprise specific target must be achieved during oneyear budget period. The success of these performance indicators would be appraised in certain period depending on target description. Most of target will be assessed on every three months (quarterly), but there are some targets measured in every semester and the end of year (annually).

The assessment for each KPI will be delivered by comparing the realization or accomplishment of each indicator and its stated target. The performance 
index (mark) is expressed using 'traffic light system', which are red, yellow, and green. Red means performance index is below $80 \%$ or poor performance, yellow refers to performance index equal to or more than $80 \%$ but less than $100 \%$ (average performance), and green denotes performance index equal to or more than $100 \%$ (excellent performance).

The examples of KPI for each objective are described in Table 1.

Table 1 presents the objectives and indicators of each scorecard perspective, including performance target for 2016 of DGDS.

1) Stakeholder perspective

The objective of this perspective is to finance budget deficit soundly in order to support fiscal sustainability through GDS management. There is one indicator to measure this objective which is percentage of deficit financing fulfillment trough GDS. In 2016, DGDS set up 100\% of achievement level for this indicator.

2) Customer perspective

This perspective has one objective which is to be credible on managing GDS. To measure its achievement, DGDS employs survey to its stakeholders, named by stakeholder satisfaction index survey. Performance target of this objective is set 3.5 on scale 4 .

3) Internal business process perspective

There are four objectives on this perspective, which are a) promoting liquid, deep, and stable GDS market, b) performing distinctive financial and GDS market analysis, c) realizing restrained cost and portfolio risk, and d) making GDS management comply to Standard Operating Procedure (SOP). The first objective has two performance indicators which are percentage of GDS market Turn-Over Ratio (TOR) and effectiveness level of education and communication of GDS management. The second one has two indicators as well, which are deviation level of 10 year bond benchmark yield to the market and timeliness index of delivering financial and GDS market analysis. The other two objectives also have two different indicators each, as detailed on the table 1.

4) Learning and growth perspective

This perspective set by four objectives, which are: (1) creating competitive human resources; (2) establishing conducive organization; (3) developing reliable information management system; and (4) pursuing optimum budget management. Performance indicator of first objective is percentage of employee that meets with hard competency standard. The second objective has two indicators, which are implementation of risk mitigation and percentage of implementation of organizational fitness index survey recommendation. The third and fourth one have one performance each, which are accuracy level and data validation of Directorate and percentage of budget realization respectively.

\subsection{Discussion on DGDS's Balanced Scorecard}

In order to address the question of this paper in which whether the concept of balanced scorecard is able to deliver accountability in public sector, here, I examine the three main questions raised in the introduction.

\subsubsection{Can the balanced scorecard ideas answer the need of accountability in public organization?}

As highlighted above that accountability, principally is about questioning an individual or agency explanation or justification for actions or performances that she or he has made, the notion of balanced scorecard is truly relevant to deal with this concern. Balanced scorecard is a framework that helps organization define and translate the vision and strategy into small piece of objectives and measures. Once objectives or measures instituted within organization, the actions or programs would be developed thoroughly and consistent to the vision achievement. This makes all organization elements, such as divisions, individuals, and other resources work out according to the actions and programs, established under balanced scorecard approach. This process then will lead to better performance and compliance whereby it is looked for by the notion of accountability.

Moreover, the use of balanced scorecard as a means of strategic and performance management can help the organization to address the notion of performance accountability, promoted by Behn (2001) and Stewart (1984) on his accountability ladder. Balanced scorecard ideas facilitate organization in designing and linking the vision and strategy of organization with comprehensive performance measures that mainly focus on outcomes achievement. Referencing to Kaplan and Norton (1996), there are three principles on how to link strategy with balanced scorecard's measures: cause and effect relationships, outcomes and performance drivers, and linkage to financials.

Organization's scorecard must tell the story of business unit's strategy through a sequence of 'if-then' statements since strategy, basically, is a set of hypotheses about cause and effect. The balanced scorecard always uses certain generic measures to explain those cause and effect relationships, reflected in outcome measures as lag indicators and performance drivers as lead indicators. For instance, the outcome is improved profit, so the drivers are number of sales, quantity of customer, amount of product, and promotion. Lastly, all measures on the scorecard should be linked to financial objectives, as these objectives are the main concerns for shareholders. Three other measures, customer, internal business process, and learning and growth 
perspective are designed to strengthen financial objectives.

Against to other methods, such as traditional approach or Management by Objective (MBO), the notion of balanced scorecard is more comprehensive and relevant addressing the accountability. In terms of organization performance, the traditional one tends to focus on financial aspects and does not consider the need of significant improvement on processes (Kaplan \& Norton 1996). MBO purely concentrates on output regardless process and input. Hence, those alternative approaches will not be able to address the issue of accountability by which requesting explanation on the procedures and processes is the principle.

\subsubsection{Does the applied balanced scorecard in DGDS address public accountability?}

In order to answer this question, it is important to look at detail on every scorecard established at the DGDS. As explained before, consistent with the organizational aims, the DGDS has replaced the financial perspective with the stakeholder perspective. According to the theory, three other perspectives within DGDS should be built to support the achievement of stakeholder perspectives. The main stakeholders of DGDS are Minister of Finance and the Government of Indonesia itself. These parties genuinely desire DGDS to find certain amount of funds for covering the budget deficit otherwise the national development and economic growth would not happen sustainably. The DGDS then establishes stakeholder perspective, which is to finance budget deficit soundly in order to support fiscal sustainability through GDS management. This perspective is designed to deliver two ladders of accountability: program and performance accountability (Stewart 1984). Additionally, in terms of relational accountability (Romzek 2000), this perspective also can be used to address hierarchical accountability to Minister of Finance. Consequently, the DGDS would not be accountable if GDS management does not succeed securing funds to cover the budget deficit soundly and prudently.

Furthermore, as mentioned above that within balanced scorecard concept, three other perspectives (customer, internal business process, and learning \& growth) should be built to support stakeholder perspective, scorecard of DGDS is supposed to be built according to what the stakeholder perspective formulates. They cannot address accountability if they are not in line and complement with the aim of financing budget deficit soundly through issuing and managing GDS to support fiscal sustainability. Thus, are other three perspectives in DGDS scorecard built to sustain stakeholder perspective? The following are the answer and analysis.

The first is customer perspective. The DGDS has established objective for customer perspective, which is 'to be credible on managing GDS'. Why it should be credible? The logic is that in order to find certain amount of fund for fulfilling budget deficit, increasing number of investors and maintaining investor confidence on GDS management are the most important concerns that DGDS has to take into account because the money is from them. Investor will not believe and buy the securities issued by the government (DGDS) if the management is not credible and transparent. Credible means management has to be professional, independent (not aligned with other interest or party, such as banks, investors, politicians), truthful, and under market best practice. Transparent refers to everything except confidential, that needs to be disclosed to the market, should be disclosed (no hidden agenda and information). Hence, it can be said that this customer perspective suggests the DGDS to perform market driver accountability to deliver public accountability.

The second is internal business process perspective. Internal business process perspective is developed to deliver the objectives of stakeholder and customer perspective (Kaplan \& Norton 1996). It is built as a sequence after stakeholder and customer perspectives have been established. The objectives make sense because in order to finance budget deficit soundly with suitable amount of fund, the securities market should be liquid, deep, and stable supported by distinctive financial and GDS market analysis and restrained cost and portfolio risk. Liquid refers to the securities are always traded by market player (investor and broker) daily and the ability of securities to be converted to cash upon the investor wants to sell the securities. Deep denotes the securities have been traded by diverse investors (i.e. bank, insurance company, pension fund, mutual fund, and securities company) in huge amount and in varied kind of securities (in terms of maturity and types). Deep market also refers to the situation whereby the securities is mostly owned by domestic investor and held by various investor, such as banks, insurance company, pension fund, mutual fund, and individual, not only dominated by certain investor. Stable means market that is free from any shock caused by domestic and global market condition.

Furthermore, to create securities management that is credible, the DGDS has to deliver distinctive financial and GDS market analysis and to realize restrained cost and portfolio risk as well. These objectives are essential since as an issuer, the DGDS has to ensure financing budget deficit through debt securities will not damage fiscal sustainability and refinancing risk. Credibility of debt securities management is actually reflected on how well the DGDS minimizes cost of fund and controls risk and fiscal sustainability. The less the DGDS exercises cost of fund and the more risk is controllable, the more credible GDS management becomes. In the end, efficient cost of fund and controllable portfolio risk will straightaway strengthen sound budget financing.

Credibility of GDS management is also supported by compliancy. Within internal business process perspective, there is one objective DGDS has to implement very implemented well, which is 
compliancy of GDS management toward Standard Operating Procedure (SOP). The SOP explains series of process or activity which must be done by every single official in the DGDS office when conducting certain business process, such as doing securities issuance, buyback, private placement, and debt switch. Public officials in the DGDS have to be accountable for what they have done in managing GDS and financing budget deficit through complying on the SOP. Once their stakeholders, among others, supreme auditor, internal auditor, superior, and society require explanation on every action they have done, they can answer it by using the SOP as the reference.

The third is learning and growth perspective. Kaplan and Norton (1996) mention that to enable three other perspectives in the balanced scorecard (financial, customer, and internal business process) to be accomplished, organization must invest in the infrastructure, among others, employee capability, information system, motivation, empowerment and alignment. According to DGDS's balanced scorecard, three objectives - developing competitive human resources, creating conducive organization, and utilizing reliable information management system have been developed in accordance to that concept. The objective of developing competitive human resources which has indicator on percentage of employee that meets with hard competency standard, is addressing concern of employee capability highlighted by Kaplan and Norton (1996). The other one, which is utilizing reliable information management system is also addressed the concern of investment on the information system. However, the other principles, motivation, empowerment, and alignment have not been yet actualized in that scorecard. There are no measures on these principles yet.

Definitely, the DGDS has to reformulate its learning and growth perspective since the absence of specific measure on this perspective will affect organizational capabilities in reaching long-run objectives and meeting with public accountability. It is important to ensure all links in the balanced scorecard are connected and integrated because once one link misses, it indicates strategic objectives do not link to organization vision.

\subsubsection{Which type of accountability the DGDS's balanced scorecard answers for?}

In this section, I examine several performance indicators to demonstrate the relevancy of scorecard in DGDS and accountability in public administration sphere. The first indicator is percentage of GDS effective cost achievement. In issuance process, the DGDS has to establish targeted effective cost that is monitored quarterly according to the scorecard. The effective cost reflects how much money that the government has to pay related to securities issuance. Cost is reflected by 'yield' that is attached on securities. The yield then converted to 'coupon' that refers to the interest that the government has to pay to the investor (securities buyer) as a consequence of the process in which the government borrows money from the investors. The coupon is counted per year, in the form of percentage, and paid by the government monthly, semi-annually or annually until the securities mature.

Indeed, it is an important issue in the securities management. The issue will push the government to be efficient in finding funds from the market. Although the DGDS has an authority to seek money from the market, this institution cannot collect money as much as it wants for financing budget deficit or particularly just for showing its performance. The DGDS is not allowed, simply for reaching target of budget financing need, they issue securities to the market disregarding the cost attached on every securities. It must be efficient since every cost caused by securities issuance would be charged from government revenues. DGDS must find funds through issuing securities in reasonable and marketable prices. This means the DGDS must be 'financially accountable', as Behn (2001) has declared on financial accountability. Public officers have an obligation to spend taxpayer's money wisely and reasonably, since principally the society will not allow their money spent in wasteful way. Taxpayers want their money come back in the form of growth, welfare, and better wellbeing.

Accordingly, by creating the indicator of targeted effective cost, which are for issuance through auction amounted to $10 \mathrm{bps}$, the DGDS wants to show the main stakeholders (Minister of Finance and Government of Indonesia) that this institution will struggle to price the securities issued through auction with maximum spread to market price amounted to 10 bps. The DGDS puts this indicator into account of financial accountability since once securities is priced in the auction, cost of fund (the coupon) of such securities will be paid from government revenue which is gathered from taxpayer. Every action of DGDS staff then will be watched and monitored through this indicator. Once they do not achieve this performance point, the superior (Minister of Finance) straightaway will require them with such accountability to find out what issues or reasons behind that. Additionally, this indicator can be also as a tool for the government encouraging DGDS officers to perform job properly and professional in one hand, and preventing fraudulence caused by DGDS employees in setting up the price or illegal deals with market or investors.

The second indicator is stakeholder satisfaction index of GDS management held by the DGDS. Stakeholder satisfaction index principally derived from the notion of customer satisfaction index that is popular in marketing sphere. Akin to customer satisfaction index in which it is an index to measure satisfaction level of customer upon product or service delivery of company, stakeholder satisfaction index is an index that expresses level of stakeholder satisfaction on how the DGDS manages the securities and serves its stakeholders. The methodology on how to measure stakeholder satisfaction index is similar with customer satisfaction index whereby the DGDS 
conducts a survey to stakeholders that are chosen based on random sampling. There are five levels in the index, which are strong satisfied $(4<\mathrm{n}<5)$, satisfied (3 $<\mathrm{n}<4)$, moderate satisfied $(2<\mathrm{n}<3)$, less satisfied ( 1 $<\mathrm{n}<2)$, and not satisfied $(0<\mathrm{n}<1)$. For this indicator, the DGDS has set up target at the level of 3.5 or 'satisfied'. This issue needs to be taken into account of accountability because stakeholder satisfaction index represents what the stakeholders think about services, credibility, and transparency in securities management.

As highlighted above that credible means professional, independent, truthful and in accordance with market best practice, and transparent refers to disclosure, the DGDS' stakeholders demand the office to show their accountability related to compliance with professionalism and best practice in the financial market. In other word, the stakeholders require the DGDS to perform professional accountability acknowledged by Romzek (2000) and process accountability, one of Stewart's ladder in accountability manners. So, is stakeholder satisfaction index able to address these types of accountability?

This question can be addressed through examining several concerns on how the DGDS delivers the survey. First is determining respondents of survey. According to description of the survey above, the DGDS exercises random sampling mechanism to decide which stakeholders would be included in respondent list. Indeed, this method is used to reduce and eliminate unfairness in stakeholder choosing process. There is no room for DGDS to design the respondent based on its interest. The DGDS will not be able to determine which stakeholders should be included or not in the survey. In addition, statistically, random sampling method is proven to create data independency. The respondents, hence, are clear from any interest, such as bias answers, DGDS's interest on stakeholders that potentially will give good answer in the survey, data manipulation conducted by the DGDS official or respondent.

Second concern is located at the concept of the survey itself. Similar to customer satisfaction index by which the survey is designed to capture what the customers feel and think about company product or service delivery, stakeholders satisfaction index is also created to obtain level of stakeholder trust on securities management. Hence, based on this concept, we can say that how accountable is DGDS, would be decided by party that directly requires explanation and answer in terms of compliance with best practice and standards or norms applied in the financial market. The investors indirectly value and measure the professionalism, credibility, transparency, and performance of DGDS. This means by measuring investor confidence index, the DGDS indirectly is trying to deliver professional and process accountability towards party that is involved in the market. If the survey result shows the index is below 2 (less or unbelievable), it denotes the DGDS does not pursue those two type of accountability since the DGDS is not credible and transparent institution for managing securities.

The third examined indicator is spread of weighted average yield (WAY) awarded with the highest yield awarded. This indicator is designed to measure fairness of price matching between benchmark yield and yield awarded. Benchmark yield is yield decided by the DGDS before conducting an auction to be a guidance for determining winner of the auction process. This yield represents maximum level of yield in which the DGDS can accept. Awarded yield is range of yield offered by investor in auction process that is accepted by DGDS. Awarded yield is always at the level or below of benchmark yield. The spread is defined by reducing highest awarded yield with WAY awarded. In financing subject, this spread known as tail. By measuring tail, accuracy of pricing and fairness of deciding the winner can be pointed out because the tail represents level of understanding of participating investors on the auction about the fairness of securities price. The successful auction is the auction that results shorter tail in which it reflects same perception among investors regarding a fair yield of securities. Short tail also indicates the DGDS's attempt on preventing from awarding small numbers of investors with bigger yield than others.

In relation with accountability, this indicator can be used as a tool for addressing accountability for fairness (Behn 2001) in which the government agency must treat society mutually or fairly and process accountability, one of accountability ladders promoted by Stewart (1984) that emphasizes equality on causes. Through measuring tail, the DGDS wants ensure all investors have been treated equally. Whole information related to securities issuance are disclosed evenly to all investors. This tail also can be used to mitigate unaccepted action conducted by a corrupt employee, such as selling profitable information to certain investors. If all tail is long, it means there is a huge gap on understanding or prediction securities price in which a small number of investors get 'good' information and on the other side, the rest (big proportion) of investors do not get good information.

\section{Conclusion}

Toward public sectors, delivering accountability is crucial aspect that needs to be in place. They have to be accountable since they are assigned with specific authority and resources. Without accountability, public official will be uncontrollable and relegate itself to seek private interests. One of ways to deliver accountability is pursuing good performance. Good performance refers to the achievement of organizational targets or objectives that are derived from vision statements. This is not effected instantly but through series of process, called performance management. One contemporary concept of performance management is balanced scorecard, pioneered by Robert S. Kaplan and David P. Norton.

Study case on the implementation of balanced 
scorecard in the DGDS shows that this concept is an attempt to deliver several concepts of accountability in public sector. Each perspective within the DGDS's balanced scorecard has been constructed to pursue the main demand of stakeholders toward the DGDS role in financing budget deficit. Mainly, two stakeholders, Minister of Finance and Government of Indonesia demand the DGDS to finance budget deficit through managing debt securities safely and efficiently. Those stakeholders not only require a hundred percent of financing completion but also the security and efficiency of those securities management as reflected on the DGDS's scorecard.

In more detail, instead of presenting hierarchical accountability, the DGDS's scorecard has also been developed to address other notions of accountability. Firstly, the indicator of percentage of GDS effective cost achievement is relevant with the notion of financial accountability. Although the DGDS has huge authority to find funds from market, it must act as efficient as possible since it deals with cost of fund that affects government revenues and taxpayers. Secondly, through conducting survey to measure stakeholder satisfaction index, the DGDS wants to ensure its credibility in securities management in which they are vital towards accountability, particularly on the concept of professional accountability and process accountability. Thirdly, the indicator of spread of WAY awarded with the highest yield awarded (tail) denotes the accuracy of pricing and fairness of the auction. The DGDS utilizes this indicator to demonstrate accountability for fairness by which whole participating investors in the auction are treated equally and evenly especially on information access. In addition, those indicators also can be used as tools for preventing fraudulence and misconduct done by corrupt employees to profit their interest or particular investors.

Nevertheless, some important aspects related to accountability are not covered yet in the DGDS's balanced scorecard. The measures on motivation and empowerment in human resources area have to be developed to support the needs of professional accountability and four ladders of accountability. These measures are vital towards organization since instead of system, employee is major issue that has significant role raising the possibility of fraud and misact. Further research and action on these issues need to be in account in order to establishing and strengthening the role of balanced scorecard and the need of accountability in the DGDS case.

\section{References}

Agca, V. \& Tuncer, E. (2006). Multidimensional performance evaluation models and a balanced score card implementation. Afyon Kocatepe University Journal of Economics and Administrative Sciences, 8(1), 173-193.
Ahmad, J. K., Devarajan, S., Khemani, S., \& Shah, S. (2005). Decentralization and service delivery. World Bank Policy Research Working Paper, (3603).

Australian House of Representatives Standing Committee (1990). Not dollars alone: review of the financial management improvement program. Australian Government Publishing Service, Canberra.

Behn, R.D. (2001). Rethinking democratic accountability. Washington DC: Brookings Institution Press.

Bovens, M. (2007). Analysing and assessing accountability: a conceptual framework. European Law Journal, 13(4), 447-468.

Fard, H.D. \& Rostamy, A.A.A. (2007). Promoting public trust in public organizations: explaining the role of public accountability. Journal of Public Organization Review, 7(1), 331-344.

Halligan, J. (2001). Accountability. In C. Aulich, J. Halligan, \& S. Nutley (Eds), Australian handbook of public sector management. (pp. 124-137). Sydney: Allen \& Unwin.

Haque, M.S. (2000). Significance of accountability under the new approach to public governance. International Review of Administrative Sciences, 66, 599-617.

Kaplan, R.S. \& Norton, D.P. (1992). The balanced scorecard - measures that drive performance. Harvard Business Review, 92105, 71-79.

Kaplan, R.S. \& Norton, D.P. (1993). Putting the balanced scorecard to work. Harvard Business Review, 93505, 4-17.

Kaplan, R.S. \& Norton, D.P. (1996). Using the balanced scorecard as a strategic management system. Harvard Business Review, 96107, 37-47.

Niven, P.R. (2003). Balanced scorecard: step by step for government and nonprofit agencies. New Jersey: John Wiley \& Sons.

Romzek, B.S. (2000). Dynamics of public sector accountability in an age of reform. International Review of Administrative Sciences, 66(1), 21-44.

Romzek, B.S. \& Dubnick, M.J. (1998). Accountability. In J.M. Shafritz (Ed), International encyclopedia of public policy and administration, Colo: Westview Press.

Siddiquee, N.A. (2011). Performance Management \& Measurements. Public Management POAD 9022, Adelaide: Flinders University, 30 May 2011. 
Stewart, J.D. (1984). The role of information in public accountability. In A. Hopgood \& C. Tomkins (Eds), Issues in public sector accounting, (pp. 13-34). Oxford: Philip Allan. 